\title{
Foreign Business Ownership and Domestic Entrepreneurial Exports
}

Piers Thompson

Nottingham Business School, Nottingham Trent University, $8^{\text {th }}$ Floor Newton Building, Burton Street, Nottingham, NG1 4BU.

piers.thompson@ntu.ac.uk

Wenyu Zang

Nottingham Business School, Nottingham Trent University, $8^{\text {th }}$ Floor Newton Building, Burton Street, Nottingham, NG1 4BU.

wenyu.zang@ntu.ac.uk

August 2016

This paper has been published in the: Journal of Small Business and Enterprise Development: $\underline{\text { http://dx.doi.org/10.1108/JSBED-10-2015-0138 }}$

Please cite as following:

Thompson, P. and Zang, W. (2015), "Foreign business ownership and domestic entrepreneurial exports", Journal of Small Business and Enterprise Development, Vol. 23 No. 3, pp. 873-895. doi: 10.1108/JSBED-10-2015-0138 


\section{Foreign Business Ownership and Domestic Entrepreneurial Exports}

\section{Structured Abstract:}

\section{Purpose}

There has been considerable debate about the impact that Foreign Direct Investment (FDI) has upon home grown enterprise (Pathak et al., 2015). This study examines how foreign business ownership at the local level affects the decision of individual UK entrepreneurs to export their production.

\section{Design/methodology/approach}

The Global Entrepreneurship Monitor (GEM) data and ONS foreign firm employment data are used within this study. In order to control for entrepreneurial and firm characteristics, a multivariate approach is adopted with logit, ordered logit and multinominal logit regressions utilised.

\section{Findings}

It is found that the influence of foreign firms, as captured by their share of local employment, has a negative influence on domestic entrepreneurs' probability of exporting, but has no significant effect on the intensity of these export activities.

\section{Research Implications}

The results suggest that local economies may not only become highly reliant on foreign employers, but also on local demand for domestic production. This means actions might be required to reduce this over-reliance to ensure the development of resilient local economies.

\section{Originality/value}

Unlike many other studies the relationship between the SME exports and foreign influence is considered at a local level. With the current UK government seeking to increase UK firms' exports substantially, understanding this relationship is of key importance to policy makers.

Key Words: domestic entrepreneurship, foreign direct investment, foreign employment, local labour markets, export intensity, export propensity

Article Classification: Research Paper

\section{Introduction}

Although, a vast majority of policy makers have sought to attract FDI (Girma et al., 2001), there has been considerable debate about the impact that FDI has upon home grown enterprise (Pathak et al., 2015). It is argued that there are often benefits for domestic enterprises in terms of serving the needs of foreign affiliates (Markusen and Venables, 1999) and knowledge spillovers relating to both technological advances (Acs et al., 2007), and management techniques (Fu, 2012). On the other hand there are also arguments that FDI brings with it added 
competition, which can weaken domestic enterprises (De Backer and Sleuwaegen, 2003). One area that is examined in much less detail is the psychological and motivational influence that factors such as a greater foreign presence in the local economy may have on domestic small and medium sized enterprises (SMEs) and the entrepreneurs that run them (De Clercq et al., 2008).

Both theoretical and empirical work has indicated that the overall effect of FDI is unclear because of the opposing positive demand and negative competition effects (Barbosa and Eiriz, 2009; Pathak et al., 2015). However, much of this research has considered the impact of foreign presence on domestic enterprises at an aggregate country level whereas even regional level analysis may miss the varying effects within a country (Figlio and Blonigen, 2000). It is also true that much of the work has considered the impact of FDI and foreign employment on the domestic SME community in terms of the final consequences such as the number of new domestic businesses created (Kim and Li, 2014). This means that existing studies have largely ignored the uneven spatial distribution of FDI and the employment it creates and not necessarily considered how the activities of existing entrepreneurs are affected. As the types of businesses created and their strategic decisions will influence whether businesses survive and whether latent entrepreneurs are encouraged to start their own businesses (Delmar et al., 2013), this line of investigation will be valuable for policy makers seeking to understand the immediate and longer term ramifications of attracting more foreign owned businesses into the localities they are responsible for.

One particular strategic choice that could influence the ability of SMEs to survive and grow is the decision to export their output (Coeurderoy et al., 2012). Given increased competition from overseas for formerly protected local markets, domestic entrepreneurs may not necessarily have an option, but must try to sell further afield to maintain their sales (Packham et al., 2005). With the current UK government seeking to increase UK firms' exports substantially, understanding how foreign firm presence influences domestic entrepreneurs is of key importance to policy makers (BIS, 2015). Given the growing literature on regional economic resilience it is also clear that such a relationship is important for the long term success of local economies as reduced reliance on local markets is likely to enable domestic enterprises to withstand localised demand shocks (Packham et al., 2005).

This study therefore has two key objectives. Firstly it seeks to understand how greater or lesser foreign presence influences the decision of domestic entrepreneurs to export their output in the first place. Secondly it considers whether foreign presence influences the degree to which domestic firms export, in other words the intensity of their export activities. The paper 
explores these from a local perspective, which has previously been ignored, but is where foreign influences on domestic enterprises are likely to be strongest. As other factors associated with the entrepreneur and business are likely to influence the propensity to export, a multivariate approach is adopted with logit, ordered logit and multinominal logit regressions utilised.

The remainder of the paper is structured as follows. The next section outlines the existing literature examining the relationship between foreign business presence and domestic SMEs, particularly that literature relating to export activities, in order to develop hypotheses relating to the primary research objectives of the paper. The third section outlines the Global Entrepreneurship Monitor (GEM) data and ONS foreign firm employment data used within this study. This section also provides detail with regard to the analysis techniques adopted. The results of the analysis are presented in the fourth section. Implications for policy makers and entrepreneurs are then outlined, before the final section concludes.

\section{Foreign Direct Investment and Exports}

This study considers both the decision to export and intensity of exporting activities where this occurs. Authors such as Bernard and Jensen (2004) have suggested that these are two separate decisions. This is because there are substantial fixed costs, which must be overcome before exporting can take place (Helpman et al., 2004; Chen et al., 2013). However, once these have been overcome increasing the intensity of these export activities does not involve similar fixed costs. This means when considering the impact of foreign influence in the local labour market on exporting, it is important to consider whether it is export propensity or intensity which is likely to be affected. This literature review covers the theoretical links in the first two subsections before considering the empirical studies of this relationship. Other entrepreneurial and firm characteristics which may influence export activities are then considered.

\section{Demand and Competition Effects}

Studies examining the influence of FDI and greater foreign influence upon domestic enterprises have suggested that there are two main effects operating in opposite directions. The first effect of a greater presence of foreign owned firms on domestic enterprises is the negative competition effect (Barbosa and Eiriz, 2009). This relates to the situation where foreign firms compete for both custom and inputs with domestic enterprises potentially forcing domestic SMEs into less profitable non-innovative niches (Hanson, 2001). In both cases this is likely to weaken domestic enterprises making it harder to make the necessary investments to enter new 
markets (Brush et al., 2002). However, it is perhaps where entrepreneurial talent is enticed into working for foreign firms that domestic firms looking to enter new markets are deprived of key resources (De Backer and Sleuwaegen, 2003). An alternative perspective is that greater competition will raise productivity or force less efficient enterprises out of the market with survivors better placed to compete in export markets (Kneller and Pisu, 2007). Given the literature outlined above it would be expected that the competition effect will primarily influence the export propensity decision:

Hypothesis 1: Greater foreign influence in the local labour market increases competition for customers and key resources reducing the entrepreneurs' export propensity.

The demand effect relates to new demand created for the output of domestic enterprises and indirectly through the adoption of new management techniques (Markusen and Venables, 1999). In some cases foreign affiliates may produce new opportunities for product development where they create a new market for their own goods, which can be imitated by domestic producers (O’Malley and O’Gorman, 2001). Moreover, backward linkages are formed when domestic firms act as the suppliers or subcontractors of foreign firms. This may help to encourage domestic enterprises to export a greater proportion of their output as they are effectively dealing with players from foreign markets thereby obtaining experience of international entrepreneurship (Barbosa and Eiriz, 2009). This may allow domestic enterprises to overcome the psychic and cultural distance between their own market and the home market of the foreign firms (Zucchella and Hagen, 2012). The demand effect may be expected to have positive influences on both export propensity and intensity as learning from interacting with foreign firms increases the understanding of foreign markets:

Hypothesis 2a: Greater foreign influence in the local labour market will increase demand for the output of domestic entrepreneurs' firms providing resources to increase entrepreneurial export propensity.

Hypothesis 2b: Where foreign influence is greater, experience supplying foreign affiliates will provide domestic entrepreneurs with the knowledge to increase their export intensity. 


\section{The Export Spillover Effect}

It has also been suggested that the presence of firms exporting in the local vicinity can also have an export-spillover effect on other firms, whereby they learn from the exporting activities of competitors (Aitken et al., 1997; Greenaway et al., 2004). With many foreign affiliates having a greater export orientation, a greater foreign presence may lead to technology and information spillovers for domestic firms (Kneller and Pisu, 2007; Anwar and Nguyen, 2011; Chen et al., 2013). The foreign firms might provide training to their employees, which can be transferred to the domestic firms as employees move from foreign to local firms or start their own businesses (De Clercq et al., 2008). Many entrepreneurs avoid exporting to reduce the risk associated with limited foreign market knowledge, where gathering such knowledge is hindered by cultural, corporate governance system and language differences (Oviatt and McDougall, 2005). Foreign affiliates could be a vital source of such knowledge, where technology and information spillovers make domestic firms more productive and competitive, reducing export marketing costs and improving the export performance of domestic firms (Chen et al., 2013). Moreover, the sunk costs of exporting associated with learning about and developing distribution channels, product regulations, and consumer tastes can be reduced (Chen et al., 2013). For those already exporting, marketing costs can be reduced allowing them to extend their export markets (Kneller and Pisu, 2007; Chen et al., 2013).

These spillovers are promoted by forward and backward linkages as Kneller and Pisu (2007) suggest foreign firms might be willing to share technology and information to achieve better production coordination and boost profits as they are not direct competitors. Therefore, domestic firms in upstream and downstream industries might benefit in terms of the quality and quantity of their products, helping them increase their exports. More formal collaboration agreements could be formed including technology sharing, cooperation on distribution contracts and innovation development (Anwar and Nguyen, 2011). As with the demand effect, export spillovers are likely to increase entrepreneurs' awareness of export opportunities, but also their skills in accessing these markets.

Hypothesis 3a: Greater foreign influence in the local labour market will demonstrate the potential for exporting, reducing fixed costs and increasing the export propensity of domestic entrepreneurs’ firms. 
Hypothesis 3b: Greater foreign influence in the local labour market will demonstrate the potential for exporting to a wider range of clients increasing the export propensity of domestic entrepreneurs’ firms.

The theoretical links between foreign influence in the labour market and entrepreneurial export activities are summarised in Figure 1 below. What should be noted is that these mechanisms are not mutually exclusive and it is possible for all three to be present with any analysis capturing the overall effect.

\section{PLEASE INSERT FIGURE 1 ABOUT HERE}

Studies considering the impact of foreign influence on other entrepreneurial decisions, such as those associated with new venture creation suggest that non-linear relationships may exist (Buckley et al., 2007). For the three effects above it would be expected that these relationships will strengthen with greater foreign influence leading to the following hypotheses:

Hypothesis 4: As foreign influence levels increase the competition effect will strengthen generating a non-linear negative relationship with entrepreneurial propensity.

Hypothesis 5a: As foreign influence levels increase the opportunity to supply foreign affiliates will increase both demand and opportunities for export spillovers, raising entrepreneurial propensity in a non-linear fashion.

Hypothesis 5b: As foreign influence levels increase the opportunity to supply foreign affiliates will increase both demand and opportunities for export spillovers, raising entrepreneurial intensity in a non-linear fashion.

However, the combination of the positive demand and spillover effects with the negative competition effect could result in other shapes to this overall relationship.

\section{Empirical evidence at regional level}

As noted in the introduction, studies have recognised that the impact of any FDI will have a non-uniform influence on the domestic enterprise in different regions of the host economy (Figlio and Blonigen, 2000). Some regions of countries such as the UK attract much more FDI 
than others (Dimitropoulou et al., 2013). Both the competition and demand effects are likely to have a much greater effect on those businesses competing for the same labour resources, and located to supply the foreign affiliates respectively. Leichenko and Erickson (1997) show export performance varies between US states, with a positive relationship found with inward FDI. Zhang and Song (2000) come to the same conclusion using Chinese provincial level data. The nature of this investment may also differ (Fallon and Cook, 2014), as will the nature of the domestic enterprise and labour resources available within different regional or local economies (Villaverde and Maza, 2015). In China FDI is found to positively affect exports in the coastal and central regions, in contrast, its impact on exports is insignificant in the western region (Sun, 2001). Of course these results must be considered in the light of the studies discussed above that suggested that a more localised geographical focus should be taken.

\section{Entrepreneurial Choices Relating to Exports}

Analysing 2104 Mexican manufacturing plants from 1986 to 1990, Aitken et al. (1997) find that the probability a domestic plant exporting is positively correlated with MNE domestic production. Greenaway et al. (2004) study the role of export spillovers within the same industry and find a positive effect from the presence of foreign firms on both export propensity and intensity in the UK. Chen et al.'s (2013) findings for China are similar where export value and intensity are increased. However, in Ireland entrepreneurs' decision to export rather than export intensity is promoted (Ruane and Sutherland, 2005). The authors suggest that this may reflect a lack of competition with domestic firms, limiting the benefits with regard to increased productivity.

Considering the types of relationship that have most effect, Kneller and Pisu (2007) find that only horizontal spillovers between firms in the same industry are present and export oriented foreign firms are the main sources of the effect. This effect is limited to export propensity rather than intensity. Anwar and Nguyen (2011) find positive export spillover effects through horizontal and forward linkages in Vietnam. However, backward linkages have a negative effect on exports, suggesting that the entry of foreign firms can increase the sunk costs associated with export activity.

In addition, the results of some studies depend on trade regime, the size of firms, the location of firms and so on. Using data of 1117 manufacturing firms in Uruguay, Kokko et al. (2001) find that the likelihood of local firms exporting increases with the presence of foreign firms established during the outward-oriented trade regime after 1973, but there is no evidence 
of export spillovers from the foreign firms established during the import-substituting trade regime before 1973.

Concentrating on the decisions of entrepreneurs, De Clercq et al. (2008) find that national level inward FDI is positively related with the proportion of export oriented new ventures in developed countries, but that this relationship becomes insignificant when other knowledge spillovers are accounted for. However, the spillover effect is negative in lower income countries. They suggest that a simpler relationship is present with knowledge spilling over from others who are exporting. Accounting for regional differences Gonzalez-Pernia and Peña-Legazkue (2012) find a positive relationship between regional level FDI and export intentions of early stage entrepreneurs in Spain. However, this does not account for variation within regions and the potential for a non-linear relationship as is found between FDI and entrepreneurial entry in some studies (Buckley et al., 2007).

\section{Entrepreneurial Influences on Exporting}

Turning to other entrepreneurial and firm level factors which may influence export decisions, studies whilst finding gender differences in entrepreneurial engagement and firm performance (Klapper and Parker, 2011), do not always find significant differences in male and female entrepreneurs' propensity to export (Westhead et al., 2001). This indicates that similar hurdles are faced by entrepreneurs of both genders (Grondin and Schaefer, 1995). However, other issues such as family roles have been found to slow exporting ambitions in some studies (Welch et al., 2008).

Human capital is expected to play a role in the decision to export and exploit such opportunities successfully. Italian evidence suggests a more highly qualified workforce increases export intensity (Cerrato and Piva, 2012). The entrepreneur's human capital appears to play a key role at even the earliest stages of business development with a positive association found with export intentions of nascent entrepreneurs (Evald et al., 2011). However, Ruzzier et al. (2007) suggest international orientation and environmental risk perception rather more general international business skills and management know-how influence the propensity to export. Ganotakis and Love (2012) indicate managerial experience, more closely associated with age, may be key for entering export markets, but in terms of export intensity it is education which is key.

One characteristic, which may capture specialist human capital relating to export markets is the immigrant status of the entrepreneur. Studies, such as Levie (2007), have suggested that those entering a region from elsewhere may have a fresh view about the 
resources available and the opportunities that they present. Immigrants may have a further advantage in that they may have a much greater economic, social and cultural insight into how business is conducted in their home country (Gould, 1994), and may even retain key business contacts that provide access to the market (Herander and Saavedra, 2005).

As well as the characteristics of entrepreneurs their motivation for engagement in an entrepreneurial career may also have an impact. Necessity driven entrepreneurs with a lack of alternative employment may view this as a temporary career change until jobs as waged employees become available (Bradbury, 1994). These entrepreneurs may lack financial backing and possess less human capital, making businesses less profitable and growth orientated (Hessels et al., 2008). Hessels and van Stel (2011) suggest that necessity entrepreneurs are less likely to have opportunities to export due to the low value added sectors that they operate in.

\section{Firm Characteristics and Export Activities}

It is understandable that businesses might be expected to gradually increase their sales to export markets overtime as they become more culturally aware of what is required (Johanson and Vahlne, 1977). However, other studies have identified examples of the born global business (Knight and Cavusgil, 2004), where technological developments such as the internet decrease the costs of reaching customers further afield (Dutta and Evrard, 1999). Moen and Servais (2002) find evidence that those SMEs exporting earlier are actually more likely to experience greater export intensity.

Larger businesses may be expected to have the resources to break into new markets (Majocchi et al., 2005). Clearly some industries may be better suited to exporting where geographical proximity is not required for transactions to take place (Higón and Driffield, 2010). Park et al. (2003) do not find any evidence of export spillovers from FDI when analysing Ukrainian manufacturing as a whole. However, they find that larger firms in urban locations producing durable goods benefit from FDI.

\section{Methods}

The main data used in this study are drawn from the GEM project, an international study of entrepreneurial activity and attitudes (Reynolds et al., 2005). For a detailed explanation of the data collection procedures in the UK see Levie (2007). Between 2005 and 2007 the GEM UK adult population survey collected data from 117,395 individuals. This study concentrates on a subsample of the data containing 6596 entrepreneurs. Although, the GEM data primarily 
focuses on the entrepreneurs rather than their businesses, where they were entrepreneurially active respondents are asked about their businesses. Studies have often used the entrepreneurial activity rates as measures of business starts or particular types of business start (De Clercq et al., 2008). This study concentrates on specific businesses that the entrepreneurs provide information about. This focus on those that are entrepreneurially active in the GEM data has been utilised in a variety of other previous studies (Gonzalez-Pernia and Peña-Legazkue, 2012; Thompson et al., 2012). Descriptions of all the variables used in the analysis are contained in the appendix in Table A1.

\section{Export Measures}

The key measure of interest in the study is the 'proportion of their customers that will normally live outside their country'. Although, an imperfect proxy, studies using the GEM data have regularly utilised this measure in order to capture the exporting activities of entrepreneurs' businesses (Acs et al., 2007; Hessels et al., 2008; Hessels and van Stel, 2011; Gonzalez-Pernia and Peña-Legazkue, 2012). As outlined in the literature review and depicted in Figure 1, there are two potential relationships that foreign influence may have on exporting activities of entrepreneurs' firms. The first is whether the firms export any of their output, their export propensity. Here we measure this in a binary manner, using a dummy variable to represent those firms that sell 1 percent or more of their output to individuals who normally reside outside the country. The GEM data capture more detail with respondents asked to indicate which range best reflects the proportion of sales to those who normally live outside the country: 0 percent; 1 to 25 percent; 26 to 50 percent; 51 to 75 percent; 76 to 90 percent; and 91 to 100 percent. This means that as well as the initial choice to export, the study can capture the export intensity of the entrepreneur's firm using an ordinal measure based on these categories.

\section{Foreign Influence Measures}

When attempting to capture foreign presence in a local economy there are many difficulties associated with data availability for FDI. Even at a regional level no official data source is available in the UK capturing either in-flows or stocks of FDI (Billington, 1999). One off estimates have been produced at the regional level (Hill and Munday, 1991). Some studies have used the number of projects as a proxy, but this doesn't necessarily capture the varying impact of investments of different sizes (Dimitropoulou et al., 2013). Stone and Peck (1996) suggest that these regional FDI figures should be treated with a degree of caution as capital invested, or worse projects, may not reflect the influence of foreign owned businesses on the local labour 
force. Some large projects in capital intensive industries may have a limited impact whilst other smaller investments in financial terms may provide a similar level of employment (Barbosa and Eiriz, 2009). Given the potential impact of the competition effect, whereby entrepreneurs will be hindered by a lack of skilled labour, it is important that this is captured by the measure of foreign influence used. To a lesser extent given the importance of entrepreneurs' networks on their firms (Pickernell et al., 2011), the impact of foreign firms in the labour market will have ramifications for any demand and knowledge spillover effects.

To overcome the data availability problems this study utilises data on employment by foreign owned firms as measured by the ONS 'Foreign Ownership of Businesses in the United Kingdom Analysis' (ONS, 2010). As noted above this measure has the benefit of potentially capturing the influence of foreign firms through the demand, competition and knowledge spillover effects more appropriately. This is based on the Value Added Tax (VAT) and Pay As You Earn (PAYE) registered units included within the Inter-Departmental Business Register (IDBR), so will ignore the smallest more informal businesses. The data is recorded at the local authority district level of which there are 380 non-overlapping areas in Great Britain. The GEM data has responses from entrepreneurially active individuals from 369 of these.

Unfortunately the data is produced on a one off basis relating to 2010. As the study is considering the longer-run impact of FDI, which may take some time to influence the entrepreneurial skills and intentions of both latent and existing entrepreneurs (De Backer and Sleuwaegen, 2003; Kim and Li, 2014), this is not necessarily a substantial problem.

The relationship between foreign influence and export propensity is explored firstly with bi-variate analysis. The local authorities are split into four equal groups based on the degree of foreign influence within their economies. This will help to identify whether there is a linear or non-linear relationship between export propensity and foreign influence (Buckley et al., 2007).

\section{Analysis Approach}

A number of other factors may influence the propensity of entrepreneurs' firms to export and the intensity of these activities. In order to control for these other influences and isolate the impact of foreign firms' influence in the local labour market, it is necessary to adopt a multivariate approach. The non-continuous nature of the variables of interest, export propensity and export intensity, precludes the use of ordinary least squares regressions. Instead the two decisions relating to exporting activities are analysed as follows. In order to examine whether greater foreign firm influence in the local labour market makes domestic SMEs more likely to 
export, binary logistic regressions are used. The dependent variable $E X P O R T_{i}$ is a dummy which takes a value of 1 if an entrepreneur indicates that at least some of their sales will be to those normally residing outside the country.

$$
\text { EXPORT }_{i}=\alpha_{0}+\beta_{1} \text { FOREIGN }_{i}+\beta_{2} \text { ENTRE }_{i}+\beta_{3} \text { FIRM }_{i}+\varepsilon_{i}
$$

The continuous variable FOREIGN captures foreign influence in the local labour market as the percentage of local employment within foreign firms. To capture any possible non-linear relationships the square of this term $\left(F O R E I G N^{2}\right)$ is also included in some specifications. To reduce collinearity problems and to make the coefficients more meaningful, the variable FOREIGN is centred around its mean value (Cohen et al., 2003). The terms ENTRE and FIRM are matrices of variables representing entrepreneurial and firm characteristics respectively that the literature suggests may be related to the decision to export.

When considering the proportion of sales that are exported, an ordered logistic regression is utilised to capture the different categories of exporting. This will operate in a similar fashion to the estimation laid out in equation (1) for the decision to export, but rather than there being a single cut-off each level of export activity is represented by the latent variable reaching a different threshold. The ordered logits may not appropriately capture the two separate decisions associated with exporting, the initial decision to export and then the intensity of these activities (Bernard and Jensen, 2004; Helpman et al., 2004). Ideally a Heckman (1979) selection approach would be used to model the two decisions together. However, this requires a variable related to the decision to export alone. Kneller and Pisu (2007) use lagged exports to represent having overcome the fixed cost of exporting, but the cross sectional nature of GEM prevents this. Instead we use a multinominal logit to identify those variables, which make nonexporting more likely relative to low export levels ( $1 \%$ to $25 \%$ of sales), and those which make high export levels (26\% or more of sales) more likely.

\section{Independent Variables - Entrepreneurial Characteristics}

Within SMEs the entrepreneur is frequently the dominant decision maker and as such their abilities, motivations and experiences are likely to influence the activities of the firm as discussed in the preceding section (Fuller-Love, 2006). In order to account for gender differences a dummy is included for male entrepreneurs. The exact age of entrepreneurs is represented by a continuous variable. A quadratic term is also included to allow for the possibility of a non-linear relationship. Both variables are centred around the mean age. There 
is also potential for a non-linear relationship between export propensity and formal education. As the exact nature as well as level of education may be important, educational attainment is captured using dummy variables to represent the highest level of qualification achieved. Four levels of education are considered: some secondary - which consists of those with no formal qualifications; secondary - GCSE or A level qualifications; post secondary - vocational qualifications and others not elsewhere classified; graduate - university Bachelor, Masters or Doctoral degrees.

Recognising the differences found in various studies relating migrant status this is measured using a three category variable. Those who have always lived in the same Government Office Region ${ }^{1}$ can then be compared to those who are more geographically mobile by including dummies to represent those who were born in the UK but in another region described as in-migrants, and those entering the UK from another country described as immigrants. Although, this is imperfect as country of origin effects may be present, the relatively small number of respondents from each country make it impractical to include dummies for each group.

Lastly the motivation behind an entrepreneurial venture is captured by whether respondents were opportunity or necessity driven. Here we include dummies for those indicating that they started their businesses to 'take advantage of a business opportunity' described as pure opportunity driven, and those who claim there was 'no better choice for work' described as pure necessity driven. These dummies allow a comparison with those indicating that there was a mix of the two motivations for their business start.

\section{Independent Variables - Firm Characteristics}

Regardless of the entrepreneur's attributes some firms will be better suited to exporting a greater proportion of their output than others (Higón and Driffield, 2010). In terms of firm characteristics, we control for the age of firm and the firm size as captured by employment. The size of the business is treated as a continuous variable, but as there is a considerable positive skew to the data the natural $\log$ is taken. For firm age we follow the accepted categorisations used in the GEM data classifying firms as: nascent - where the firm is in the earliest stages of development and has not paid wages or salaries for three months or more; new businesses - where the firm has paid wages and salaries for between three and 42 months;

\footnotetext{
${ }^{1}$ There are twelve Government Office Regions (GORs) in the UK consisting of the nine English regions (North East, North West, Yorkshire and Humber, East Midlands, West Midlands, East of England, London, South East, and South West), and the three devolved regions (Wales, Scotland, and Northern Ireland).
} 
and established businesses - where the business has paid profits for 42 months or more. We also control for the industry of the firm measured at the 1-digit Standard Industrial Classification (SIC) level to capture differences in the suitability of firms' outputs for export. Dummies are also included to capture the year and region of interview to reflect changing economic conditions, which may also have an influence.

\section{Results}

Table 1 below presents the proportion of entrepreneurs exporting some of their output when the sample is split into quartiles based on the level of foreign influence in the local labour market.

\section{PLEASE INSERT TABLE 1 ABOUT HERE}

Just under a third of entrepreneurs indicate they sell some of their output to customers not normally based in the UK (31.2 percent). The localities with the lowest levels of foreign firm employment are those with the highest proportion of exporters (35.4 percent), but there is less variation in the remaining three quarters of the sample (29.2 percent to 31.1 percent). The chisquare statistic indicates the variation in export activity is statistically significant. This negative relationship runs contrary to the findings of Gonzalez-Pernia and Peña-Legazkue (2012) in Spain and De Clercq et al.'s (2008) national level results. Thus, the negative competition effect (hypothesis H1) appears more apparent.

Table 2 presents the results when considering the export intensity of domestic firm's activities. A majority of those firms that export (60.6 percent of those firms that export any output) are only doing this on a relatively minor scale.

\section{PLEASE INSERT TABLE 2 ABOUT HERE}

In the localities with the lowest level of foreign employment, the proportion of firms displaying higher levels of export intensity is greater than in the other localities. For the remainder of the sample the pattern is not as clear. For example, for the second quartile 7.5 percent of firms export a majority of their output, but for the third quartile where there is more foreign influence in the labour market the equivalent proportion is 8.3 percent. This would be consistent with those firms that are able to overcome the fixed costs of exporting and any negative effects of 
the competition effect, being able to learn through demand (hypothesis $2 b$ ) and export spillover effects (hypothesis $3 b$ ) and increase their degree of export intensity.

\section{Export Propensity Regressions}

In preparation for the multivariate analysis, Table 3 below presents the bivariate correlations of the variables used in the regression analysis. The non-parametric Spearman rank correlation coefficients are used as a number of the variables are ordinal rather than continuous in nature. Confirming the findings above foreign influence in the labour market is negatively correlated with the level of exports.

\section{PLEASE INSERT TABLE 3 ABOUT HERE}

Exports are associated with the human capital resources in the firms as captured by the entrepreneurs' educational attainment (Evald et al., 2011); experience from other regions or countries (Levie, 2007; Herander and Saavedra, 2005), and opportunity orientation (Bradbury, 1994). The stage of business development is negatively associated with exporting (Knight and Cavusgil, 2004). The correlation coefficients do not indicate any problems with multicollinearity. The variance inflation factors (VIFs) in the regressions confirm this.

The logit regressions of export propensity explain a relatively small proportion of the deviation according to the pseudo $\mathrm{R}^{2}$ values (Table 4). However, the null of a good fit to the data cannot be rejected by the Hosmer-Lemeshow test. The LR-test suggests that the null of a constant probability can be rejected at the 1 percent level.

\section{PLEASE INSERT TABLE 4 ABOUT HERE}

The regression confirms a negative relationship between the degree of foreign influence in the local labour market and export propensity, significant at the 1 percent level. When the quadratic term is added this is positive. This combination of coefficients would be consistent with domestic entrepreneurs being initially put off exporting due to the competition effect (hypothesis 1), but beyond a certain level of foreign presence the linkages within the locality may become sufficiently intertwined that export spillovers occur (hypothesis 5a). However, such a relationship cannot be confirmed as the positive coefficient on the quadratic term is insignificant. What is clear is that there is no support for hypotheses $2 a$ and $3 a$ that greater foreign influence in the labour market encourages more entrepreneurs to export some output 
through demand or export spillover effects. This is consistent with studies such as Crone and Watts (2000) which have found multinationals in the UK to source less than 2 percent of their inputs from domestic enterprises. However, this runs contrary to studies such as Kneller and Pisu (2007) that find a positive export spillover effect, although they acknowledge this may reflect some foreign exporters seeking out locations with high export potential. Unlike regional studies in the US (Leichenko and Erickson, 1997), and China (Zhang and Song, 2000), when the local level foreign influence is considered results are consistent with additional pressures building in the output and input markets that entrepreneurs rely upon.

Supporting the findings of previous studies, those entrepreneurs holding university qualifications (Evald et al., 2011), and a wider geographical experience (both within the UK and from abroad) which may increase their international orientation (Ruzzier et al., 2007), are more likely to export. The positive effect of firm size may reflect the availability of human capital resources within the firm (Majocchi et al., 2005; Cerrato and Piva, 2012). Those entrepreneurs in the earliest stages of business development may be basing their measures of exports more on ambitions or expectations than reality leading to the positive coefficient, but it may also reflect the dynamic born global nature of some new businesses (Cavusgil and Knight, 2014).

\section{Export Intensity Regressions}

The ordered logits of export intensity produce very similar results to those relating to export propensity with a negative relationship found between export levels and the local foreign influence (Table 5). This was not expected as the competition effect was presumed to be most pertinent for export propensity through making it harder to overcome the fixed costs of exporting. The quadratic term is once again positive, but insignificant and fails to improve the regression according to the information criterion indicating a lack of support for hypothesis $5 b$. The ordered logits therefore provide no evidence to support the positive impact of foreign firms through the demand and export spillover effects (hypotheses $2 b$ and $3 b$ ).

\section{PLEASE INSERT TABLE 5 ABOUT HERE}

Allowing for the separation of the decisions to export and choice over the level of intensity Table 6 below presents the multinominal logits. 
Greater foreign presence in the local labour market increases the probability of not exporting relative to being involved in low levels of export activities. This confirms earlier results consistent with the competition effect (hypothesis 1). However, equations for high levels of exports suggest that foreign influence is not a negative factor. Instead a positive, although insignificant coefficient is estimated. This would be consistent with firms that choose to export being better placed to increase the intensity of their export activities thanks to the positive export spillover effects from their dealings with foreign affiliates (Greenaway et al., 2004). Overall results imply that competition disadvantages more firms so that they struggle to overcome the fixed costs of exporting, but those productive enough to achieve this are not disadvantaged in exploiting these markets (Kneller and Pisu, 2007). Given the lack of a significant positive coefficient there is no statistical evidence for hypotheses $2 b$ and $3 b$.

Male entrepreneurs and higher educational qualifications are significantly related to export intensity rather than the decision to export in first place. In terms of migration the results suggest the more geographically mobile are better able to spot the availability of business opportunities including those in export markets (Levie, 2007). However, only those from other countries are significantly more likely to export a high proportion of sales, possibly through knowledge of and connections in other countries (Gould, 1994; Herander and Saavedra, 2005). Clearly human capital in terms of both formal qualifications and international experience are key and these entrepreneurs would seem to be best placed to gain from any export spillovers. Nascent entrepreneurs' expectations appear to be more positive both in terms of export propensity and intensity. Employment is only positively associated with the decision to export as the fixed costs are easier to overcome.

\section{Implications}

The existing literature made it unclear whether a positive or negative relationship was to be expected between exporting and foreign influence from FDI (Ruane and Sutherland, 2005; Kneller and Pisu, 2007; Gonzalez-Pernia and Peña-Legazkue, 2012). Although more existing studies suggested a positive export-spillover effect (Greenaway et al., 2004), this may have in part reflected a limited focus on where localised competition effects are most acute and the large number of entrepreneurs and the extremely small enterprises not captured in many existing datasets. In particular, the competition for inputs is not just restricted to existing businesses, but will affect the choices made by latent entrepreneurs, with the more talented potentially choosing waged employment with foreign multinationals instead (Grossman, 1984; 
Martins, 2011). This may have ramifications where foreign firms skim the most talented local employees from domestic enterprises (De Backer and Sleuwaegen, 2003; Martins, 2011). It may also cause problems for lagging more peripheral localities that are likely to experience net outmigration stripping the locality of the most creative and entrepreneurially minded individuals associated with export orientated business development (Grossman, 1984; Casson, 1995; De Backer and Sleuwaegen, 2003; Martins, 2011).

This may mean that attracting FDI to create employment opportunities may weaken the local economy by creating a reliance on multinationals less embedded in the local economy (Simmie and Martin, 2010). But where entrepreneurial individuals are retained by foreign employment, this international business experience can be used in future venture creation with an export orientation (O’Malley and O’Gorman, 2001; Ruzzier et al., 2007). The study found that those with greater educational attainment were more likely to export. The results imply that graduate entrepreneurs with their stronger networks (Pickernell et al., 2011), should be encouraged where local and national policy makers wish to increase the export potential of their areas. These latent entrepreneurs are likely to be those benefiting from employment in foreign affiliates (O’Malley and O’Gorman, 2001). Policy makers would be advised to target support, both in terms of advice and financial support, at these more highly qualified entrepreneurs with experience working for foreign affiliates.

The results associated with export intensity suggest negative competition effects may be offset by positive export spillovers for those that do export. This further makes the case for providing support to those who are best placed from their experiences to increase export intensity. The study found that this includes not just the more highly qualified, but also those with greater geographical mobility who take a novel view of local resources and opportunities (Levie, 2007), as well as having first-hand experience of the markets they may seek to exploit (Gould, 1994; Herander and Saavedra, 2005). With a predisposition to exporting activities it is these groups of entrepreneurs who will potentially gain most from export spillovers. This means that local policy makers looking to boost export driven entrepreneurship would need an open culture that helped overcome the barriers that new entrants to the area may face, such as language difficulties, which provide a further barrier to accessing finance for business starts (Bruder et al., 2011).

Given the potential benefits of FDI in terms of employment creation and other knowledge spillovers (Porter and Ketels, 2003), the negative result does not indicate that policymakers should change policy from attracting FDI to dissuading it. Instead it is important the policymakers are aware of all the influences of greater foreign firm ownership and 
employment at the local level. Given that backward vertical linkages have been found to be associated with exporting activities (Kneller and Pisu, 2007), policymakers may need to encourage domestic entrepreneurs to recognise the opportunities to use foreign affiliates as a first step in accessing international markets to ensure local economies can withstand exogenous shocks. This may be achieved through the provision of tailored business training to increase awareness from the side of the local entrepreneurs. However, when developing FDI policy it is important that appropriate incentives are linked to conditions that ensure foreign affiliates are more embedded within local supply chains. For individual entrepreneurs the results presented here indicate that a greater influence in the local labour market by foreign firms is likely to inhibit their export propensity, but if the fixed costs are overcome there is no evidence that export intensity is constrained. This implies domestic entrepreneurs' focus should be on exploiting new markets through foreign firms rather than protecting existing markets.

\section{Conclusions}

This study has utilised a large sample of entrepreneurs from the UK to further investigate the relationship between foreign business influence and exporting activities of domestic entrepreneurs. Unlike previous studies the study examined the impact of foreign business ownership at the local level rather than the regional level. This allows for the potential variation of FDI effects within regions to be captured (Figlio and Blonigen, 2000). The study also considered both the propensity to export and the intensity of export activity. This local focus appears critical in understanding how competition hinders entrepreneurs by repressing their export propensity. Less evidence is found for a negative effect from competition on export intensity. In fact, the positive, but insignificant results found in the multinominal logits suggest this is being offset by positive export spillover effects (Greenaway et al., 2004).

Although the study was able to make use of a more localised measure of foreign influence, this does also bring with it limitations. At the local level it is hard to differentiate the motivations of investing firms with current data. These different motivations for investing multinationals may influence the effect of FDI on domestic export activity (Franco, 2013). As positive relationships between exporting activities and FDI are likely to reflect knowledge spillovers, Gonzalez-Pernia and Peña-Legazkue (2012) suggest that it would be beneficial to control for the absorptive capacity of entrepreneurs, or account for the size of the knowledge gap (Girma et al., 2001). To fully capture the knowledge gap more detailed data regarding the types of investment being made would be required. Such research may be better tackled through case study analysis of specific localities where more detailed primary data can be 
collected covering production and research activities, as well as networking activities and relationships formed with domestic firms.

The cross sectional nature of the GEM and foreign influence data prevents causal links to be fully identified. In order to understand the balance of the mechanisms at play qualitative analysis with a longitudinal nature would be of value to isolate exactly how entrepreneurs react to the environment created by large foreign employers in their local area.

The other benefits of FDI may ensure that it still remains attractive for policymakers, but the results here mean the negative possibilities must be balanced against any gains. Given the results here there is an implication that policymakers should not just wait for positive spillovers to occur, but to encourage entrepreneurs and foreign businesses to take advantage of the opportunities available, particularly those with higher human capital and international experience who are better placed to exploit them.

\section{References}

Acs, Z.J., O’Gorman, C., Szerb, L. and Terjesen, S. (2007), "Could the Irish miracle be repeated in Hungary”, Small Business Economics, Vol. 28 No. 2/3, pp. 123-142.

Aitken, B., Hanson, H.G. and Harrison, A.E. (1997), "Spillovers, foreign investment, and export behaviour”, Journal of International Economics, Vol. 43 No. 1, pp. 103-132.

Anwar, S. and Nguyen, L.P. (2011), "Foreign direct investment and export spillovers: evidence from Vietnam”, International Business Review, Vol. 20 No. 2, pp. 177-193.

Barbosa, N. and Eiriz, V. (2009), "The role of inward foreign direct investment on entrepreneurship”, International Entrepreneurship and Management Journal, Vol. 5 No. 3, pp. 319-339.

Bernard, A. and Jensen, J.B. (2004), "Why some firms export”, Review of Economics and Statistics, Vol. 86 No. 2, pp. 628-639.

Billington, N. (1999), “The location of foreign direct investment: an empirical analysis”, Applied Economics, Vol. 31 No. 1, pp. 65-76.

BIS (Department for Business, Innovation and Skills) (2015), BIS Performance Indicators: number of UK businesses helped to improve their performance through internationalisation, Department for Business, Innovation and Skills, London.

Bradbury, K.L. (1994), "New England job changes during the recession: the role of selfemployment”, New England Economic Review, Vol. September/October, pp. 45-57. 
Bruder, J., Neuberger, D. and Räthke-Döppner, S. (2011), "Financial constraints of ethnic entrepreneurship: evidence from Germany”, International Journal of Entrepreneurial Behaviour and Research, Vol. 17, No. 3, pp. 296-313.

Brush, C.G., Edelman, L.F. and Manolova, T. (2002), “The impact of resources on small firm internationalization”, Journal of Small Business Strategy, Vol. 13 No. 1, pp. 1-17.

Buckley, P.J., Clegg, J. and Wang, C. (2007), “Is the relationship between inward FDI and spillover effects linear? An empirical examination of the case of China”, Journal of International Business Studies, Vol. 38 No. 3, pp. 447-459.

Casson, M. (1995), Entrepreneurship and business culture: studies in the economic of trust Volume 1, Edward Elgar, Cheltenham.

Cavusgil, S.T. and Knight, G. (2014), “The born global firm: an entrepreneurial and capabilities perspective on early and rapid internationalization”, Journal of International Business Studies, Vol. 46 No. 1, pp. 3-16.

Cerrato, D. and Piva, M. (2012), “The internationalization of small and medium-sized enterprises: the effect of family management, human capital and foreign ownership”, Journal of Management and Governance, Vol. 16 No. 4, pp. 617-644.

Chen, C., Sheng, Y. and Findlay, C. (2013), “Export spillovers of FDI on China's domestic firms”, Review of International Economics, Vol. 21 No. 5, pp. 841-856.

Coeurderoy, R., Cowling, M., Licht, G. and Murray, G. (2012), "Young firm internationalization and survival: empirical tests on a panel of 'adolescent' new technologybased firms in Germany and the UK”, International Small Business Journal Vol. 30 No. 5, pp. 472-492.

Cohen, J., Cohen, P., West, S.G. and Aiken, L.S. (2003), Applied multiple regression/correlation analysis for the behavioral sciences: third edition, Lawrence Erlbaum Associates, Mahwah, NJ.

Crone, M. and Watts, H.D. (2000), "MNE supply linkages and the local SME sector: evidence from Yorkshire and Humberside”, Local Economy, Vol. 15 No. 4, pp. 325-337.

De Backer, K. and Sleuwaegen, L. (2003), “Does foreign direct investment crowd out domestic entrepreneurship”, Review of Industrial Organization, Vol. 22 No. 1, pp. 67-84.

De Clercq, D., Hessels, J. and van Stel, A. (2008), “Knowledge spillovers and new ventures’ export orientation”, Small Business Economics, Vol. 31 No. 3, pp. 283-303.

Delmar, F., McKelvie, A. and Wennberg, K. (2013), “Untangling the relationships among growth, profitability and survival in new firms”, Technovation, Vol. 33 No. 8/9, pp. 276-291. 
Dimitropoulou, D., McCann, P. and Burke, S.P. (2013), “The determinants of the location of foreign direct investment in UK regions”, Applied Economics, Vol. 45 No. 27, pp. 3853-3862. Dutta, S. and Evrard, P. (1999), “Information technology and organisation within European small enterprises”, European Management Journal, Vol. 17 No. 3, pp. 239-251.

Evald, M.R., Klyver, K. And Christensen, P.R. (2011), “The effect of human capital, social capital, and perceptual values on nascent entrepreneurs' export intentions”, Journal of International Entrepreneurship, Vol. 9 No. 1, pp. 1-19.

Fallon, G. and Cook, M. (2014), “Explaining manufacturing and non-manufacturing inbound FDI location in five UK regions”, Tijdschrift voor economische en sociale geografie, Vol. 105 No. 3, pp. 331-348.

Figlio, D.N. and Blonigen, B.A. (2000), “The effects of foreign direct investment on local communities”, Journal of Urban Economics, Vol. 48 No. 2, pp. 338-363.

Franco, C. (2013), "Exports and FDI motivations: empirical evidence from the U.S. foreign subsidiaries”, International Business Review, Vol. 22 No. 5, pp. 47-62.

Fu, X. (2012), “Foreign direct investment and managerial knowledge spillovers through the diffusion of management practices”, Journal of Management Studies, Vol. 49 No. 5, pp. 970999.

Fuller-Love, N. (2006), “Management development in small firms”, International Journal of Management Reviews, Vol. 8 No. 3, pp. 175-190.

Ganotakis, P. and Love, J.H. (2012), "Export propensity, export intensity and firm performance: the role of the entrepreneurial founding team”, Journal of International Business Studies, Vol. 43 No. 8, pp. 693-718.

Girma, S., Greenaway, D. and Wakelin, K. (2001), "Who benefits from foreign direct investment in the UK”, Scottish Journal of Political Economy, Vol. 48 No. 2, pp. 119-133.

Gonzalez-Pernia, J.L. and Peña-Legazkue, I. (2012), “Regional FDI, technological knowledge and export-orientated entrepreneurs in Spain”, Paper presented at Employment Related Services Association (ERSA) Conference, 21-25 August, Bratislava.

Gould, D.M. (1994), "Immigrant links to the home country: empirical implications for U.S. bilateral trade flows”, Review of Economics and Statistics, Vol. 76 No. 2, pp. 302-316.

Greenaway, D., Sousa, N. and Wakelin, K. (2004), “Do domestic firms learn to export from multinationals”, European Journal of Political Economy, Vol. 20 No. 4, pp. 1027-1043.

Grondin, D. and Schaefer, N. (1995), "Differences in the export activities of female-and maleowned small and medium-sized enterprises”, Women in Management Review, Vol. 10 No. 8, pp. 4-10. 
Grossman, G.M. (1984), “International trade, foreign investment, and the formation of the entrepreneurial class”, American Economic Review, Vol. 74 No. 4, pp. 605-614.

Hanson, G.H. (2001), “Should countries promote foreign direct investment”, G-24 Discussion Paper Series, No. 9, United Nations, New York and Geneva.

Heckman, J.J. (1979), “Sample selection bias as a specification error”, Econometrica, Vol. 47 No. 1, pp. 153-161.

Helpman, E., Melitz, M. and Yeaple, S. (2004), “Export versus FDI with heterogeneous firms”, American Economic Review, Vol. 94 No. 1, pp. 300-316.

Herander, M.G. and Saavedra, L.A. (2005), "Exports and the structure of immigrant-based networks: the role of geographic proximity”, Review of Economics and Statistics, Vol. 87 No. 2, pp. 323-335.

Hessels, J., van Gelderen, M. and Thurik, R. (2008), "Entrepreneurial aspirations, motivations, and their drivers”, Small Business Economics, Vol. 31 No. 3, pp. 323-339.

Hessels, J. and van Stel, A. (2011), "Entrepreneurship, export orientation, and economic growth”, Small Business Economics, Vol. 37 No. 2, pp. 255-268.

Higón, D.A. and Driffield, N. (2010), "Exporting and innovation performance: analysis of the annual Small Business Survey in the UK”, International Small Business Journal, Vol. 29 No. 1, pp. 4-24.

Hill, S., and Munday, M. (1991), “The UK regional distribution of foreign direct investment: analysis and determinants”, Regional Studies, Vol. 26, No. 6, pp. 535-544.

Johanson, J. and Vahlne, J-E. (1977), “The internationalisation process of the firm: a model of knowledge development and increasing foreign market commitments”, Journal of International Business Studies, Vol. 8 No. 1, pp. 23-32.

Kim, P.H. and Li, M. (2014), "Injecting demand through spillovers: foreign direct investment, domestic socio-political conditions, and host-country entrepreneurial activity”, Journal of Business Venturing, Vol. 29 No. 2, pp. 210-231.

Klapper, L.F. and Parker, S.C. (2011), “Gender and the business environment for new firm creation”, World Bank Research Observer, Vol. 26 No. 2, pp. 237-257.

Kneller, R. and Pisu, M. (2007), “Industrial linkages and export spillovers from FDI”, World Economy, Vol. 30 No. 1, pp. 105-134.

Knight, G.A. and Cavusgil, S.T. (2004), "Innovation, organisational capabilities, and the bornglobal firm”, Journal of International Business Studies, Vol. 35 No. 2, pp. 124-141.

Kokko, A., Zejan, M. and Tansini, R. (2001), "Trade regimes and spillover effects of FDI: evidence from Uruguay”, Weltwirtschaftliches Archiv, Vol. 137 No. 1, pp. 124-149. 
Leichenko, R.M. and Erickson, R.A. (1997), “Foreign direct investment and state export performance”, Journal of Regional Science, Vol. 37 No. 2, pp. 307-329.

Levie, J.D. (2007), “Immigration, in-migration, ethnicity and entrepreneurship in the United Kingdom”, Small Business Economics, Vol. 28 No. 2/3, pp. 143-169.

Majocchi, A., Bacchioccji, E. and Mayrhofer, U. (2005), "Firm size, business experience and export intensity in SMEs: a longitudinal approach to complex relationships”, International Business Review, Vol. 14 No. 6, pp. 719-738.

Markusen, J.R. and Venables, A.J. (1999), "Foreign direct investment as a catalyst for industrial development”, European Economic Review, Vol. 43 No. 2, pp. 335-356.

Martins, P. (2011), "Paying more to hire the best? Foreign firms, wages and worker mobility”, Economic Inquiry, Vol. 49 No. 2, pp. 349-363.

Moen, Ø. and Servais, P. (2002), "Born global or gradual global? Examining the export behaviour of small and medium-sized enterprises”, Journal of International Market, Vol. 10 No. 3, pp. 49-72.

O’Malley, E. and O’Gorman, C. (2001), “Competitive advantage in the Irish indigenous software industry and the role of inward foreign direct investment”, European Planning Studies, Vol. 9 No. 3, pp. 303-321.

ONS (Office for National Statistics) (2010), "Foreign ownership of businesses in the United Kingdom”, Office for National Statistics, London.

Oviatt, B.M. and McDougall, P.P. (2005), “Defining international entrepreneurship and modelling the speed of internationalization”, Entrepreneurship Theory and Practice, Vol 29 No. 5, pp. 537-554.

Packham, G., Brooksbank, D., Miller, C. and Thomas, B. (2005), “Climbing the mountain: management practice adoption in growth oriented firms in Wales”, Small Business and Enterprise Development, Vol. 12 No. 4, pp. 482-497.

Park, S.-M., Talavera, O. and Lutz, S. (2003) The effects of regional and industry: wide FDI spillovers on export of Ukrainian firms, Centre for European Economic Research Discussion Papers, No 03-54, Mannheim, Germany.

Pathak, S., Laplume, A. and Xavier-Oliveira, E. (2015), "Inbound foreign direct investment and domestic entrepreneurial activity”, Entrepreneurship and Regional Development, Vol. 27 No. 5/6, pp. 334-356.

Pickernell, D., Packham, G., Jones, P., Miller, C. and Thomas, B. (2011), “Graduate entrepreneurs are different: they access more resources?”, International Journal of Entrepreneurial Behavior and Research, Vol. 17 No. 2, pp. 183-202. 
Porter, M. and Ketels, C.H.M. (2003), “UK competitiveness: moving to the next stage”, Economic Papers, No. 3, Department of Trade and Industry (DTI), London, UK.

Reynolds, P.D., Bosma, N., Autio, E., Hunt, S., De Bono, D., Servais, I., Lopez-Garcia, L. and Chin, N. (2005), “Global Entrepreneurship Monitor: data collection design and implementation 1998-2003”, Small Business Economics, Vol. 24 No. 3, pp. 205-231.

Ruane, F. and Sutherland, J. (2005), “Foreign direct investment and export spillovers: how do export platforms fare”, Discussion Paper, No. 58, Institute for International Integration Studies (IIIS), The University of Dublin, Dublin.

Ruzzier, M., Antoncic, B., Hisrich, R.D. and Konecnik, M. (2007), “Human capital and SME internationalization: a structural equation modelling study”, Canadian Journal of Administrative Sciences, Vol. 24 No. 1, pp. 15-29.

Simmie, J. and Martin, R. (2010), “The economic resilience of regions: towards an evolutionary approach”, Cambridge Journal of Regions, Economy and Society, Vol. 3 No. 1, pp. 27-43.

Stone, I. and Peck, F. (1996), "The foreign-owned manufacturing sector in UK peripheral regions, 1978-1993: restructuring and comparative performance”, Regional Studies, Vol. 30 No. 1, pp. 55-68.

Sun, H. (2001), “Foreign direct investment and regional export performance in China”, Journal of Regional Science, Vol. 41 No. 2, pp. 317-336.

Thompson, P., Kwong, C.C.Y. and Jones-Evans, D. (2012), "Enterprise education and the adoption of new technologies within small firms”, in Groen, A., Oakey, R., Van Der Sijde, P. and Cook, G. (Eds.), New Technology-Based Firms in the New Millennium - Volume 9, Emerald, Bingley, pp. 5-22.

Villaverde, J. and Maza, A. (2015), “The determinants of inward foreign direct investment: evidence from the European regions”, International Business Review, Vol. 24 No. 2, pp. 209223.

Welch, C.L., Welch, D.E. and Hewerdine, L. (2008), “Gender and export behaviour: evidence from women-owned enterprises”, Journal of Business Ethics, Vol. 83 No. 1, pp. 113-126.

Westhead, P., Wright, M. and Ucbasaram, D. (2001), “The internationalization of new and small firms: a resource-based view”, Journal of Business Venturing, Vol. 16 No. 4, pp. 333358.

Zhang, K.H. and Song, S. (2000), “Promoting exports: the role of inward FDI in China”, China Economics Review, Vol. 11 No. 4, pp. 385-396. 
Zucchella, A. and Hagen, B. (2012), “The international growth of e-commerce ventures”, in Harris, S., Kuivalainen, O. and Stoyanova, V. (Eds.), International Business: New Challenges, New Forms, New Perspectives, Palgrave-Macmillan, Basingstoke, pp. 137-153.

PLEASE INSERT TABLE A1 ABOUT HERE 
Table 1: Proportion of exporters by influence of foreign firms in the labour market

\begin{tabular}{lcc}
\hline Foreign Influence & Exporters & $N$ \\
\hline Lowest Quartile & $35.4 \%$ & 1645 \\
Second Quartile & $31.1 \%$ & 1654 \\
Third Quartile & $29.2 \%$ & 1652 \\
Fourth Quartile & $29.2 \%$ & 1645 \\
& & \\
Total & $31.2 \%$ & 6596 \\
& & \\
& 19.489 & \\
Chi-square & {$[3]$} & \\
& $(0.000)$ & \\
\hline
\end{tabular}

Notes: degrees of freedom in square brackets; $p$-values in parentheses 
Table 2: Degree of exporting by influence of foreign firms in the labour market

\begin{tabular}{|c|c|c|c|c|c|c|c|c|}
\hline & Exports & None & $\begin{array}{l}1 \text { to } \\
25 \%\end{array}$ & $\begin{array}{c}26 \text { to } \\
50 \%\end{array}$ & $\begin{array}{l}51 \text { to } \\
75 \%\end{array}$ & $\begin{array}{l}76 \text { to } \\
90 \%\end{array}$ & $\begin{array}{l}91 \text { to } \\
100 \%\end{array}$ & $N$ \\
\hline \multirow{6}{*}{$\begin{array}{l}\text { Foreign } \\
\text { Influence }\end{array}$} & $\begin{array}{l}\text { Lowest } \\
\text { Quartile }\end{array}$ & $64.6 \%$ & $20.5 \%$ & $5.1 \%$ & $3.7 \%$ & $2.7 \%$ & $3.4 \%$ & 1645 \\
\hline & $\begin{array}{l}\text { Second } \\
\text { Quartile }\end{array}$ & $68.9 \%$ & $20.0 \%$ & $3.6 \%$ & $3.1 \%$ & $1.7 \%$ & $2.7 \%$ & 1654 \\
\hline & $\begin{array}{l}\text { Third } \\
\text { Quartile }\end{array}$ & $70.8 \%$ & $17.6 \%$ & $3.3 \%$ & $4.0 \%$ & $1.8 \%$ & $2.5 \%$ & 1652 \\
\hline & $\begin{array}{l}\text { Fourth } \\
\text { Quartile }\end{array}$ & $70.8 \%$ & $17.4 \%$ & $3.9 \%$ & $3.3 \%$ & $1.8 \%$ & $2.9 \%$ & 1645 \\
\hline & Total & $68.8 \%$ & $18.9 \%$ & $4.0 \%$ & $3.5 \%$ & $2.0 \%$ & $2.9 \%$ & 6596 \\
\hline & Chi-square & 30.440 & [15] & $(0.010)$ & & & & \\
\hline
\end{tabular}

Notes: degrees of freedom in square brackets; $p$-values in parentheses 
Table 3: Spearman rank correlation coefficients of export intensity, foreign Influence in the labour market and independent variables

\begin{tabular}{|c|c|c|c|c|c|c|c|c|}
\hline & 1. Exports & $\begin{array}{l}\text { 2. Foreign } \\
\text { Influence }\end{array}$ & 3. Male & 4. Age & $\begin{array}{l}\text { 5. Educational } \\
\text { Attainment }\end{array}$ & $\begin{array}{l}\text { 6. Reasons for } \\
\text { Starting Business }\end{array}$ & $\begin{array}{l}\text { 7. Migrant } \\
\text { Status }\end{array}$ & $\begin{array}{l}\text { 8. Stage of } \\
\text { Business } \\
\text { Development }\end{array}$ \\
\hline $\begin{array}{l}\text { 2. Foreign Influence in } \\
\text { Labour Market }\end{array}$ & $\begin{array}{l}-0.044 \\
(0.000)\end{array}$ & & & & & & & \\
\hline 3. Male & $\begin{array}{c}0.010 \\
(0.399)\end{array}$ & $\begin{array}{c}0.001 \\
(0.908)\end{array}$ & & & & & & \\
\hline 4. Age & $\begin{array}{l}-0.007 \\
(0.582)\end{array}$ & $\begin{array}{l}-0.067 \\
(0.000)\end{array}$ & $\begin{array}{c}0.110 \\
(0.000)\end{array}$ & & & & & \\
\hline $\begin{array}{l}\text { 5. Educational } \\
\text { Attainment }^{\mathrm{a}}\end{array}$ & $\begin{array}{c}0.091 \\
(0.000)\end{array}$ & $\begin{array}{l}-0.005 \\
(0.670)\end{array}$ & $\begin{array}{l}-0.047 \\
(0.000)\end{array}$ & $\begin{array}{l}-0.067 \\
(0.000)\end{array}$ & & & & \\
\hline $\begin{array}{l}\text { 6. Reason for Starting } \\
\text { Business }^{b}\end{array}$ & $\begin{array}{l}-0.026 \\
(0.034)\end{array}$ & $\begin{array}{l}-0.033 \\
(0.007)\end{array}$ & $\begin{array}{c}0.013 \\
(0.278)\end{array}$ & $\begin{array}{l}0.056 \\
(0.000)\end{array}$ & $\begin{array}{l}-0.109 \\
(0.000)\end{array}$ & & & \\
\hline 7. Migrant Status ${ }^{c}$ & $\begin{array}{c}0.106 \\
(0.000)\end{array}$ & $\begin{array}{l}-0.008 \\
(0.536)\end{array}$ & $\begin{array}{l}-0.060 \\
(0.000)\end{array}$ & $\begin{array}{l}0.056 \\
(0.000)\end{array}$ & $\begin{array}{c}0.251 \\
(0.000)\end{array}$ & $\begin{array}{l}-0.038 \\
(0.002)\end{array}$ & & \\
\hline $\begin{array}{l}\text { 8. Stage of Business } \\
\text { Development }{ }^{d}\end{array}$ & $\begin{array}{l}-0.105 \\
(0.000)\end{array}$ & $\begin{array}{l}-0.054 \\
(0.000)\end{array}$ & $\begin{array}{c}0.102 \\
(0.000)\end{array}$ & $\begin{array}{c}0.320 \\
(0.000)\end{array}$ & $\begin{array}{l}-0.113 \\
(0.000)\end{array}$ & $\begin{array}{c}0.053 \\
(0.000)\end{array}$ & $\begin{array}{l}-0.103 \\
(0.000)\end{array}$ & \\
\hline 9. Employment & $\begin{array}{c}0.009 \\
(0.473)\end{array}$ & $\begin{array}{c}-0.002 \\
(0.887)\end{array}$ & $\begin{array}{c}0.078 \\
(0.000)\end{array}$ & $\begin{array}{c}0.075 \\
(0.000)\end{array}$ & $\begin{array}{c}-0.018 \\
(0.150)\end{array}$ & $\begin{array}{l}-0.073 \\
(0.000)\end{array}$ & $\begin{array}{l}-0.044 \\
(0.000)\end{array}$ & $\begin{array}{c}0.444 \\
(0.000)\end{array}$ \\
\hline
\end{tabular}

Notes: p-values in parentheses; (a) higher values represent higher of educational attainment such as graduate qualifications; (b) higher values represent more necessity driven motivations; (c) higher values represent more geographically mobile respondents, i.e. those entering the region from other countries;

(d) higher values represent those firms in the later stages of development. 
Table 4: Logit regressions of exporting some sales

\begin{tabular}{|c|c|c|c|}
\hline & Model 0 & Model 1 & Model 2 \\
\hline \multicolumn{4}{|c|}{ Foreign Influence on Labour Market } \\
\hline Foreign Influence & & $\begin{array}{c}-0.0255 \\
(0.000)\end{array}$ & $\begin{array}{r}-0.0290 \\
(0.000)\end{array}$ \\
\hline Foreign Influence ${ }^{2}$ & & & $\begin{array}{l}0.0008 \\
(0.276)\end{array}$ \\
\hline Male & $\begin{array}{l}0.1199 \\
(0.059)\end{array}$ & $\begin{array}{l}0.1181 \\
(0.064)\end{array}$ & $\begin{array}{l}0.1203 \\
(0.059)\end{array}$ \\
\hline \multicolumn{4}{|l|}{ Experience } \\
\hline Age & $\begin{array}{c}-0.0023 \\
(0.440)\end{array}$ & $\begin{array}{c}-0.0026 \\
(0.391)\end{array}$ & $\begin{array}{c}-0.0027 \\
(0.379)\end{array}$ \\
\hline $\operatorname{Age}^{2}$ & $\begin{array}{l}0.0386 \\
(0.097)\end{array}$ & $\begin{array}{l}0.0375 \\
(0.107)\end{array}$ & $\begin{array}{l}0.0374 \\
(0.108)\end{array}$ \\
\hline \multicolumn{4}{|c|}{ Educational Attainment - Reference } \\
\hline Some Secondary & $\begin{array}{l}0.1080 \\
(0.319)\end{array}$ & $\begin{array}{l}0.1087 \\
(0.317)\end{array}$ & $\begin{array}{l}0.1095 \\
(0.313)\end{array}$ \\
\hline Post Secondary & $\begin{array}{r}-0.1417 \\
(0.140)\end{array}$ & $\begin{array}{c}-0.1404 \\
(0.144)\end{array}$ & $\begin{array}{r}-0.1397 \\
(0.146)\end{array}$ \\
\hline Graduate & $\begin{array}{l}0.2989 \\
(0.000)\end{array}$ & $\begin{array}{l}0.2918 \\
(0.000)\end{array}$ & $\begin{array}{l}0.2908 \\
(0.000)\end{array}$ \\
\hline \multicolumn{4}{|c|}{ Migrant Status - Reference Category: Life } \\
\hline In-Migrants & $\begin{array}{l}0.2682 \\
(0.000)\end{array}$ & $\begin{array}{l}0.2573 \\
(0.000)\end{array}$ & $\begin{array}{l}0.2533 \\
(0.000)\end{array}$ \\
\hline Immigrants & $\begin{array}{l}0.4086 \\
(0.000)\end{array}$ & $\begin{array}{l}0.4173 \\
(0.000)\end{array}$ & $\begin{array}{l}0.4154 \\
(0.000)\end{array}$ \\
\hline \multicolumn{4}{|c|}{ Category: Mix of Opportunity and Necessity } \\
\hline Pure Opportunity & $\begin{array}{c}-0.0741 \\
(0.376)\end{array}$ & $\begin{array}{c}-0.0639 \\
(0.446)\end{array}$ & $\begin{array}{c}-0.0657 \\
(0.433)\end{array}$ \\
\hline Pure Necessity & $\begin{array}{c}-0.1489 \\
(0.112)\end{array}$ & $\begin{array}{c}-0.1483 \\
(0.114)\end{array}$ & $\begin{array}{c}-0.1502 \\
(0.110)\end{array}$ \\
\hline \multicolumn{4}{|c|}{ Stage of Business Development - Reference } \\
\hline Nascent & $\begin{array}{l}0.6795 \\
(0.000)\end{array}$ & $\begin{array}{l}0.6922 \\
(0.000)\end{array}$ & $\begin{array}{l}0.6953 \\
(0.000)\end{array}$ \\
\hline New Business & $\begin{array}{l}0.0213 \\
(0.777)\end{array}$ & $\begin{array}{l}0.0347 \\
(0.645)\end{array}$ & $\begin{array}{l}0.0354 \\
(0.639)\end{array}$ \\
\hline \multicolumn{4}{|l|}{$\underline{\text { Firm Size }}$} \\
\hline Log of Employees & $\begin{array}{l}0.2012 \\
(0.000)\end{array}$ & $\begin{array}{l}0.2037 \\
(0.000)\end{array}$ & $\begin{array}{l}0.2043 \\
(0.000)\end{array}$ \\
\hline
\end{tabular}

Notes: $p$-values in parentheses 
Table 4: continued

\begin{tabular}{lccc}
\hline & Model 0 & Model 1 & Model 2 \\
\hline Constant & -1.1546 & -1.0945 & -1.1261 \\
& $(0.000)$ & $(0.000)$ & $(0.000)$ \\
$N$ & & & \\
& 6596 & 6596 & 6596 \\
LR-test & 1011.3 & 1030.9 & 1032.1 \\
d.f. & {$[35]$} & {$[36]$} & {$[37]$} \\
p-value & $(0.000)$ & $(0.000)$ & $(0.000)$ \\
& & & \\
$R^{2}$ & 0.124 & 0.126 & 0.126 \\
AIC & & & \\
SIC & 7250.5 & 7232.9 & 7233.7 \\
& 7495.1 & 7484.3 & 7491.9 \\
Hosmer-Lemeshow & & & \\
& 7.64 & 5.68 & 5.47 \\
Percentage correct & $(0.469)$ & $(0.683)$ & $(0.707)$ \\
\hline $\begin{array}{l}\text { Notes: p-values in parentheses; controls also included for industry, year of survey, and government } \\
\text { office region }\end{array}$ & & &
\end{tabular}


Table 5: Ordered logit regressions of degree of exporting activity

\begin{tabular}{|c|c|c|c|}
\hline & Model 0 & Model 1 & Model 2 \\
\hline \multicolumn{4}{|c|}{ Foreign Influence on Labour Market } \\
\hline Foreign Influence & & $\begin{array}{r}-0.0217 \\
(0.000)\end{array}$ & $\begin{array}{r}-0.0256 \\
(0.000)\end{array}$ \\
\hline Foreign Influence ${ }^{2}$ & & & $\begin{array}{l}0.0008 \\
(0.201)\end{array}$ \\
\hline Male & $\begin{array}{l}0.1494 \\
(0.013)\end{array}$ & $\begin{array}{l}0.1497 \\
(0.013)\end{array}$ & $\begin{array}{l}0.1520 \\
(0.012)\end{array}$ \\
\hline \multicolumn{4}{|l|}{ Experience } \\
\hline Age & $\begin{array}{r}-0.0010 \\
(0.726)\end{array}$ & $\begin{array}{c}-0.0012 \\
(0.669)\end{array}$ & $\begin{array}{r}-0.0013 \\
(0.650)\end{array}$ \\
\hline Age $^{2}$ & $\begin{array}{l}0.0400 \\
(0.070)\end{array}$ & $\begin{array}{l}0.0391 \\
(0.076)\end{array}$ & $\begin{array}{l}0.0389 \\
(0.078)\end{array}$ \\
\hline \multicolumn{4}{|c|}{ Educational Attainment - Reference } \\
\hline Some Secondary & $\begin{array}{l}0.1152 \\
(0.267)\end{array}$ & $\begin{array}{l}0.1167 \\
(0.261)\end{array}$ & $\begin{array}{l}0.1172 \\
(0.259)\end{array}$ \\
\hline Post Secondary & $\begin{array}{c}-0.1399 \\
(0.131)\end{array}$ & $\begin{array}{r}-0.1397 \\
(0.132)\end{array}$ & $\begin{array}{l}-0.1388 \\
(0.134)\end{array}$ \\
\hline Graduate & $\begin{array}{l}0.3140 \\
(0.000)\end{array}$ & $\begin{array}{l}0.3085 \\
(0.000)\end{array}$ & $\begin{array}{l}0.3071 \\
(0.000)\end{array}$ \\
\hline \multicolumn{4}{|c|}{ Migrant Status - Reference Category: Life } \\
\hline In-Migrants & $\begin{array}{l}0.2480 \\
(0.000)\end{array}$ & $\begin{array}{l}0.2374 \\
(0.000)\end{array}$ & $\begin{array}{l}0.2328 \\
(0.000)\end{array}$ \\
\hline Immigrants & $\begin{array}{l}0.4515 \\
(0.000)\end{array}$ & $\begin{array}{l}0.4567 \\
(0.000)\end{array}$ & $\begin{array}{l}0.4554 \\
(0.000)\end{array}$ \\
\hline \multicolumn{4}{|c|}{ Category: Mix of Opportunity and Necessity } \\
\hline Pure Opportunity & $\begin{array}{c}-0.0711 \\
(0.371)\end{array}$ & $\begin{array}{l}-0.0627 \\
(0.431)\end{array}$ & $\begin{array}{c}-0.0644 \\
(0.419)\end{array}$ \\
\hline Pure Necessity & $\begin{array}{c}-0.1198 \\
(0.180)\end{array}$ & $\begin{array}{c}-0.1186 \\
(0.185)\end{array}$ & $\begin{array}{c}-0.1201 \\
(0.180)\end{array}$ \\
\hline \multicolumn{4}{|c|}{ Stage of Business Development - Reference } \\
\hline Nascent & $\begin{array}{l}0.6788 \\
(0.000)\end{array}$ & $\begin{array}{l}0.6906 \\
(0.000)\end{array}$ & $\begin{array}{l}0.6937 \\
(0.000)\end{array}$ \\
\hline New Business & $\begin{array}{l}0.0765 \\
(0.290)\end{array}$ & $\begin{array}{l}0.0899 \\
(0.214)\end{array}$ & $\begin{array}{l}0.0906 \\
(0.211)\end{array}$ \\
\hline \multicolumn{4}{|l|}{$\underline{\text { Firm Size }}$} \\
\hline Log of Employees & $\begin{array}{l}0.1655 \\
(0.000)\end{array}$ & $\begin{array}{l}0.1673 \\
(0.000)\end{array}$ & $\begin{array}{l}0.1679 \\
(0.000)\end{array}$ \\
\hline
\end{tabular}

Notes: $p$-values in parentheses 
Table 5: continued

\begin{tabular}{lccc}
\hline & Model 0 & Model 1 & Model 2 \\
\hline Threshold 1\% to 25\% & 1.087 & 1.037 & 1.071 \\
Threshold 26\% to 50\% & 2.388 & 2.341 & 2.376 \\
Threshold 51\% to 75\% & 2.843 & 2.795 & 2.830 \\
Threshold 76\% to 90\% & 3.445 & 3.398 & 3.433 \\
Threshold 91\% to 100\% & 4.003 & 3.956 & 3.991 \\
$N$ & & & \\
$N$ & 6596 & 6596 & 6596 \\
LR-test & & & \\
d.f. & 918.7 & 934.4 & 936.0 \\
p-value & {$[35]$} & {$[36]$} & {$[37]$} \\
& $(0.000)$ & $(0.000)$ & $(0.000)$ \\
$R^{2}$ & & & \\
& 0.070 & 0.071 & 0.071 \\
AIC & 12324.4 & 12310.6 & 12311.0 \\
SIC & 12596.1 & 12589.2 & 12596.3 \\
\hline Notes: p-values in parentheses; controls also included for industry, year of survey, and government \\
office region & & &
\end{tabular}


Table 6: Multinominal logit regressions for no exports, low and high exporting activity

\begin{tabular}{|c|c|c|c|c|}
\hline \multirow[b]{2}{*}{ Exports } & \multicolumn{2}{|c|}{ Model 1} & \multicolumn{2}{|c|}{ Model 2} \\
\hline & None & High & None & High \\
\hline \multicolumn{5}{|c|}{ Foreign Influence on Labour Market } \\
\hline Foreign Influence & $\begin{array}{l}0.0291 \\
(0.000)\end{array}$ & $\begin{array}{l}0.0096 \\
(0.302)\end{array}$ & $\begin{array}{l}0.0290 \\
(0.000)\end{array}$ & $\begin{array}{l}0.0025 \\
(0.812)\end{array}$ \\
\hline Foreign Influence ${ }^{2}$ & & & $\begin{array}{l}0.0001 \\
(0.913)\end{array}$ & $\begin{array}{l}0.0014 \\
(0.217)\end{array}$ \\
\hline Male & $\begin{array}{r}-0.0324 \\
(0.673)\end{array}$ & $\begin{array}{l}0.2010 \\
(0.052)\end{array}$ & $\begin{array}{r}-0.0319 \\
(0.678)\end{array}$ & $\begin{array}{l}0.2064 \\
(0.047)\end{array}$ \\
\hline \multicolumn{5}{|l|}{ Experience } \\
\hline Age & $\begin{array}{l}0.0046 \\
(0.206)\end{array}$ & $\begin{array}{l}0.0058 \\
(0.233)\end{array}$ & $\begin{array}{l}0.0046 \\
(0.207)\end{array}$ & $\begin{array}{l}0.0056 \\
(0.244)\end{array}$ \\
\hline Age $^{2}$ & $\begin{array}{l}-0.0165 \\
(0.560)\end{array}$ & $\begin{array}{l}0.0441 \\
(0.239)\end{array}$ & $\begin{array}{l}-0.0164 \\
(0.563)\end{array}$ & $\begin{array}{l}0.0443 \\
(0.238)\end{array}$ \\
\hline \multicolumn{5}{|c|}{$\begin{array}{l}\text { Educational Attainment - Reference Category: } \\
\text { Secondary Education }\end{array}$} \\
\hline Some Secondary & $\begin{array}{r}-0.0323 \\
(0.806)\end{array}$ & $\begin{array}{l}0.2191 \\
(0.224)\end{array}$ & $\begin{array}{r}-0.0323 \\
(0.806)\end{array}$ & $\begin{array}{l}0.2202 \\
(0.221)\end{array}$ \\
\hline Post Secondary & $\begin{array}{l}0.1065 \\
(0.348)\end{array}$ & $\begin{array}{l}-0.0958 \\
(0.570)\end{array}$ & $\begin{array}{l}0.1069 \\
(0.346)\end{array}$ & $\begin{array}{r}-0.0935 \\
(0.579)\end{array}$ \\
\hline Graduate & $\begin{array}{l}-0.1587 \\
(0.059)\end{array}$ & $\begin{array}{l}0.3036 \\
(0.007)\end{array}$ & $\begin{array}{l}-0.1586 \\
(0.059)\end{array}$ & $\begin{array}{l}0.3018 \\
(0.007)\end{array}$ \\
\hline \multicolumn{5}{|c|}{ Migrant Status - Reference Category: Life } \\
\hline In-Migrants & $\begin{array}{r}-0.2196 \\
(0.005)\end{array}$ & $\begin{array}{l}0.1097 \\
(0.321)\end{array}$ & $\begin{array}{l}-0.2206 \\
(0.005)\end{array}$ & $\begin{array}{l}0.1018 \\
(0.358)\end{array}$ \\
\hline Immigrants & $\begin{array}{l}-0.2619 \\
(0.048)\end{array}$ & $\begin{array}{l}0.3478 \\
(0.038)\end{array}$ & $\begin{array}{l}-0.2607 \\
(0.049)\end{array}$ & $\begin{array}{l}0.3456 \\
(0.039)\end{array}$ \\
\hline \multicolumn{4}{|c|}{ Motivation for Business Start - Reference } & Category: Mix of Opportunity and Necessity \\
\hline Pure Opportunity & $\begin{array}{l}0.0050 \\
(0.961)\end{array}$ & $\begin{array}{c}-0.1447 \\
(0.288)\end{array}$ & $\begin{array}{l}0.0052 \\
(0.959)\end{array}$ & $\begin{array}{r}-0.1486 \\
(0.275)\end{array}$ \\
\hline Pure Necessity & $\begin{array}{l}0.1934 \\
(0.090)\end{array}$ & $\begin{array}{l}0.1054 \\
(0.490)\end{array}$ & $\begin{array}{l}0.1935 \\
(0.090)\end{array}$ & $\begin{array}{l}0.1011 \\
(0.508)\end{array}$ \\
\hline \multicolumn{5}{|c|}{$\begin{array}{l}\text { Stage of Business Development-Reference } \\
\text { Category: Established Business }\end{array}$} \\
\hline Nascent & $\begin{array}{l}-0.5640 \\
(0.000)\end{array}$ & $\begin{array}{l}0.3218 \\
(0.011)\end{array}$ & $\begin{array}{l}-0.5637 \\
(0.000)\end{array}$ & $\begin{array}{l}0.3281 \\
(0.010)\end{array}$ \\
\hline New Business & $\begin{array}{l}0.0981 \\
(0.285)\end{array}$ & $\begin{array}{l}0.3281 \\
(0.009)\end{array}$ & $\begin{array}{l}0.0980 \\
(0.286)\end{array}$ & $\begin{array}{l}0.3301 \\
(0.009)\end{array}$ \\
\hline \multicolumn{5}{|l|}{ Firm Size } \\
\hline Log of Employees & $\begin{array}{l}-0.2408 \\
(0.000)\end{array}$ & $\begin{array}{l}-0.0878 \\
(0.045)\end{array}$ & $\begin{array}{l}-0.2411 \\
(0.000)\end{array}$ & $\begin{array}{l}-0.0860 \\
(0.050)\end{array}$ \\
\hline
\end{tabular}

Notes: $p$-values in parentheses 
Table 6: continued

\begin{tabular}{lcccc}
\hline & \multicolumn{2}{c}{ Model 1 } & \multicolumn{2}{c}{ Model 2 } \\
\hline Exports & None & High & None & High \\
\hline Constant & 2.5051 & 0.9758 & 2.5017 & 0.9160 \\
& $(0.000)$ & $(0.001)$ & $(0.000)$ & $(0.003)$ \\
$N$ & & & & \\
& 6596 & & 6596 & \\
LR-test & & & & \\
d.f. & 1542.5 & & 1544.9 & \\
p-value & {$[72]$} & & {$[74]$} & \\
& $(0.000)$ & & $(0.000)$ & \\
$R^{2}$ & & & 0.141 & \\
& 0.141 & & & \\
AIC & & 9561.3 & \\
SIC & 9559.7 & 10077.7 & \\
\hline
\end{tabular}

Notes: p-values in parentheses; controls also included for industry, year of survey, and government office region 
Table A1 - Distribution and Descriptive Statistics of Main Variables

\begin{tabular}{|c|c|c|c|c|c|}
\hline Variable & Category & Percentage & Mean & $\begin{array}{l}\text { Standard } \\
\text { Deviation }\end{array}$ & Skewness \\
\hline \multirow{6}{*}{$\begin{array}{l}\text { Exports - Proportion of } \\
\text { Sales to Those Not } \\
\text { Residing in the UK }\end{array}$} & $0 \%$ & 68.8 & $\mathrm{n} / \mathrm{a}$ & $\mathrm{n} / \mathrm{a}$ & $\mathrm{n} / \mathrm{a}$ \\
\hline & 1 to $25 \%$ & 18.9 & $\mathrm{n} / \mathrm{a}$ & $\mathrm{n} / \mathrm{a}$ & $\mathrm{n} / \mathrm{a}$ \\
\hline & 26 to $50 \%$ & 4.0 & $\mathrm{n} / \mathrm{a}$ & $\mathrm{n} / \mathrm{a}$ & $\mathrm{n} / \mathrm{a}$ \\
\hline & 51 to $75 \%$ & 3.5 & $\mathrm{n} / \mathrm{a}$ & $\mathrm{n} / \mathrm{a}$ & $\mathrm{n} / \mathrm{a}$ \\
\hline & 76 to $90 \%$ & 2.0 & $\mathrm{n} / \mathrm{a}$ & $\mathrm{n} / \mathrm{a}$ & $\mathrm{n} / \mathrm{a}$ \\
\hline & 91 to $100 \%$ & 2.9 & $\mathrm{n} / \mathrm{a}$ & $\mathrm{n} / \mathrm{a}$ & $\mathrm{n} / \mathrm{a}$ \\
\hline $\begin{array}{l}\text { Foreign Influence - } \\
\text { Percentage of local } \\
\text { employment in foreign } \\
\text { owned firms }^{\mathrm{a}}\end{array}$ & & $\mathrm{n} / \mathrm{a}$ & 11.9 & 5.3 & 0.9 \\
\hline Gender & Male & 64.4 & $\mathrm{n} / \mathrm{a}$ & $\mathrm{n} / \mathrm{a}$ & $\mathrm{n} / \mathrm{a}$ \\
\hline $\mathrm{Age}^{\mathrm{b}}$ & & $\mathrm{n} / \mathrm{a}$ & 44.2 & 10.6 & -0.1 \\
\hline \multirow{4}{*}{$\begin{array}{l}\text { Education - Highest } \\
\text { qualification achieved }\end{array}$} & Some Secondary & 9.8 & $\mathrm{n} / \mathrm{a}$ & $\mathrm{n} / \mathrm{a}$ & $\mathrm{n} / \mathrm{a}$ \\
\hline & Secondary & 40.2 & $\mathrm{n} / \mathrm{a}$ & $\mathrm{n} / \mathrm{a}$ & $\mathrm{n} / \mathrm{a}$ \\
\hline & Post Secondary & 13.7 & $\mathrm{n} / \mathrm{a}$ & $\mathrm{n} / \mathrm{a}$ & $\mathrm{n} / \mathrm{a}$ \\
\hline & Graduate & 36.3 & $\mathrm{n} / \mathrm{a}$ & $\mathrm{n} / \mathrm{a}$ & $\mathrm{n} / \mathrm{a}$ \\
\hline \multirow{3}{*}{ Migrant Status } & $\begin{array}{l}\text { Life-long residents of } \\
\text { region }\end{array}$ & 40.5 & $\mathrm{n} / \mathrm{a}$ & $\mathrm{n} / \mathrm{a}$ & $\mathrm{n} / \mathrm{a}$ \\
\hline & $\begin{array}{l}\text { In-migrants from } \\
\text { another UK region }\end{array}$ & 50.5 & $\mathrm{n} / \mathrm{a}$ & $\mathrm{n} / \mathrm{a}$ & $\mathrm{n} / \mathrm{a}$ \\
\hline & Immigrants & 9.0 & $\mathrm{n} / \mathrm{a}$ & $\mathrm{n} / \mathrm{a}$ & $\mathrm{n} / \mathrm{a}$ \\
\hline \multirow{3}{*}{ Motivation } & Pure Opportunity Drive & 57.4 & $\mathrm{n} / \mathrm{a}$ & $\mathrm{n} / \mathrm{a}$ & $\mathrm{n} / \mathrm{a}$ \\
\hline & $\begin{array}{l}\text { Mix of Opportunity and } \\
\text { Necessity Driven }\end{array}$ & 27.0 & $\mathrm{n} / \mathrm{a}$ & $\mathrm{n} / \mathrm{a}$ & $\mathrm{n} / \mathrm{a}$ \\
\hline & Pure Necessity Driven & 15.6 & $\mathrm{n} / \mathrm{a}$ & $\mathrm{n} / \mathrm{a}$ & $\mathrm{n} / \mathrm{a}$ \\
\hline \multirow{3}{*}{ Stage of Development } & Established Business & 48.4 & $\mathrm{n} / \mathrm{a}$ & $\mathrm{n} / \mathrm{a}$ & $\mathrm{n} / \mathrm{a}$ \\
\hline & New Business & 26.4 & $\mathrm{n} / \mathrm{a}$ & $\mathrm{n} / \mathrm{a}$ & $\mathrm{n} / \mathrm{a}$ \\
\hline & Nascent & 25.2 & $\mathrm{n} / \mathrm{a}$ & $\mathrm{n} / \mathrm{a}$ & $\mathrm{n} / \mathrm{a}$ \\
\hline \multirow{2}{*}{ Size - Employment ${ }^{c}$} & Employees & $\mathrm{n} / \mathrm{a}$ & 10.7 & 159.0 & 36.5 \\
\hline & Log of Employees & $\mathrm{n} / \mathrm{a}$ & 0.6 & 1.1 & 2.3 \\
\hline
\end{tabular}

Notes: (a) the foreign influence measure is centred around the mean in the regression analysis; (b) the age variable is centred around the mean in the regression analysis; (c) the extreme skew of the employment data makes it appropriate to use natural logs in regressions. 
Figure 1 - Theoretical Links Between Foreign Influence and Entrepreneurial Export Activities

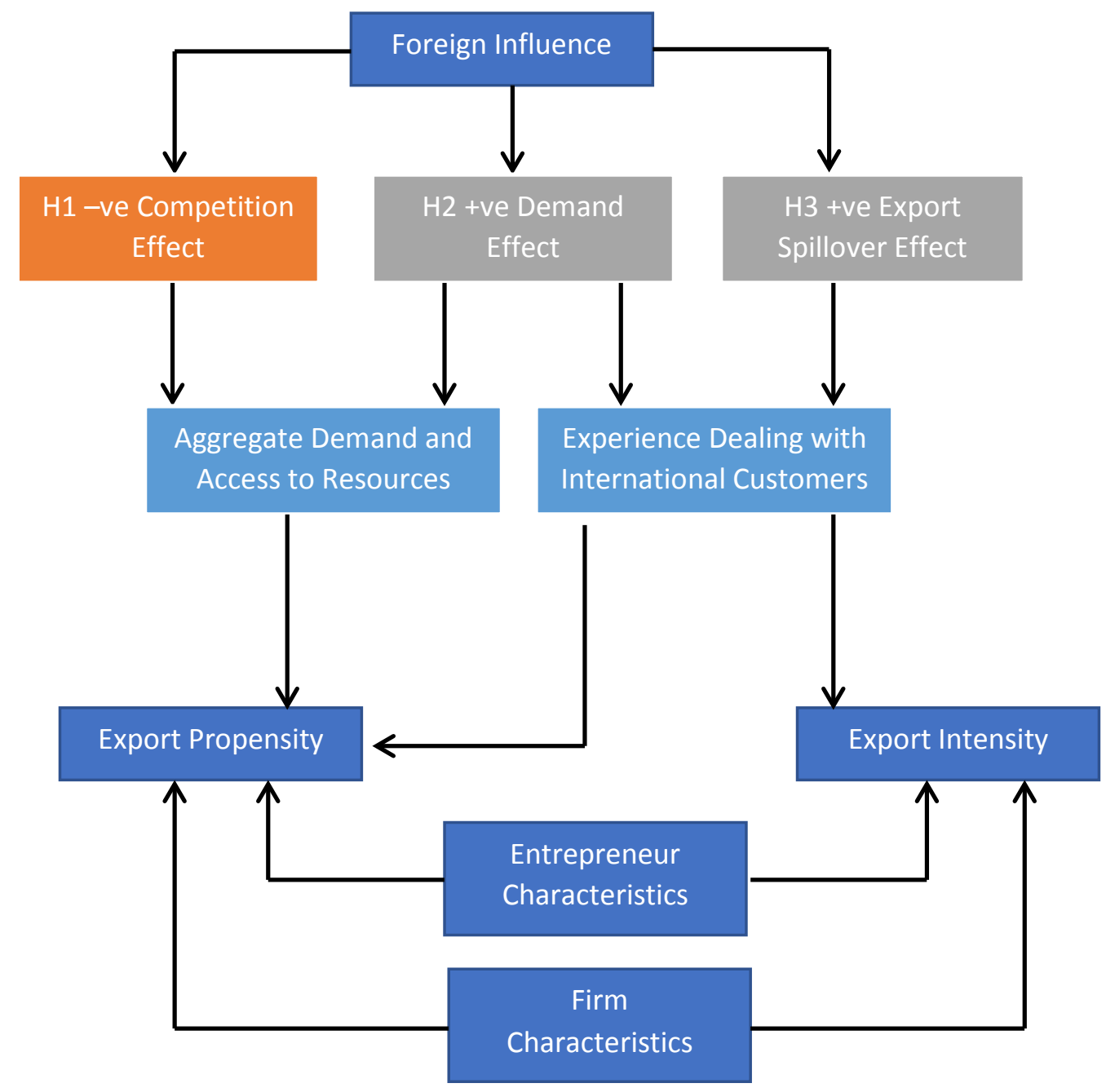

